\title{
Assessment of microbial biomass and enzyme activities in soil under temperate fruit crops in north western himalayan region
}

\author{
S. Debnath ${ }^{1 *}$, A. K. Patra ${ }^{2}$, N. Ahmed ${ }^{1}$, S. Kumar ${ }^{1}$, B. S. Dwivedi ${ }^{2}$ \\ ${ }^{1}$ Central Institute of Temperate Horticulture. Regional Station. Mukteshwar-263 138 India. \\ ${ }^{2}$ Division of Soil Science and Agriculture. Regional Station, Indian, New Delhi- 110 012, India \\ *Corresponding author: sovan_rocks@rediffmail.com
}

\begin{abstract}
Microbial communities are important for the functioning of the ecosystem, both in relation to direct interactions with the plants and with regard to nutrient and organic matter recycling. A study in field condition was undertaken in Kashmir valley to reveal the effect of various temperate fruit crops viz. apricot, peach, plum and cherry along with a control (no-plantation) on microbial biomass carbon (MBC), nitrogen (MBN), phosphorus (MBP) and dehydrogenase, phosphomonoesterase (acid and alkaline) and urease activities in soil at two different depths $(0-20$ and 21-40 cm). All the fruit crops showed a sharp decline in microbial biomass and enzyme activities with the increase in soil depth. Each of the four fruit crops showed significant $(p<0.05)$ impact on MBC over the control and the maximum MBC was recorded in plum (1000 $\left.\mathrm{mg} \mathrm{kg}^{-1}\right)$ and the lowest value was observed in control $\left(457 \mathrm{mg} \mathrm{kg}^{-1}\right)$, at the surface layer. Since there is a relationship between MBC and MBN, the similar trend was also observed in MBN as in case of MBC. For MBP, fruit crops showed any significant effect neither on surface soil, nor on subsurface soil layer over control. At the surface layer, unlike microbial biomass the highest dehydrogenase activity was observed in peach $\left(318 \mu \mathrm{g}\right.$ TPF $\left.\mathrm{g} \mathrm{soil}^{-1} \mathrm{~h}^{-1}\right)$ and the lowest value $(166 \mu \mathrm{g}$ TPF g soil $^{-1} \mathrm{~h}^{-1}$ ) was attained at control plot. Maximum alkaline phosphomonoesterase activity was observed in peach (381 $\mu \mathrm{g}$ PNP g soil-1 $\left.\mathrm{h}^{-1}\right)$, although for acid phosphomonoesterase the highest value recorded in apricot (306 $\mu \mathrm{g}$ PNP $\mathrm{g}$ soil $\left.^{-1} \mathrm{hr}^{-1}\right)$, at surface soil. A significant positive correlation $(p<0.01)$ was observed amongst MBC, MBN and MBP. Both the phosphomonoesterase activities were significantly $(p<0.05)$ correlated with MBP in soil. It can be concluded that the influence of the studied fruit crops on the soil was not uniform, in terms of the measured parameters.
\end{abstract}

Keywords: Enzyme activity, Kashmir valley, microbial biomass, soil depth, temperate fruit crops 


\section{Introduction}

The North Western Himalayan Region (NWHR) of India is bestowed with temperate climate. The horticulture in this region viz. Jammu and Kashmir, Himachal Pradesh and Uttarakhand, is the backbone of these states economy which supports about 1.52.0 million families and, provides direct or indirect employment to 8-10 million peoples with revenue of more than 1 billion $\$$ (USD) annually. The temperate fruit orchards are highly intense system which represents an important export industry for India. The major temperate stone fruits of India like apricot (Prunus armeniaca L.), peach (Prunus persica L.), plum (Prunus domestica L.) and cherry (Prunus avium $\mathrm{L}$.), belonging to the family of Rosaceae, are mostly grown in NWHR with an area and production of 17,397 ha and 48,200 mt for apricot; 20,314 ha and $90,842 \mathrm{mt}$ for peach; $25,831 \mathrm{ha}$ and $72,307 \mathrm{mt}$ for plum; 3,900 ha and 11,823 mt for cherry (NHB, 2012)

Plant's active root system releases about $17 \%$ of photosynthate captured in the form of organic compounds into the rhizosphere, most of which is available to the soil microbial biomass (Nguyen, 2003). Microbial communities are important for the functioning of the ecosystem (Patra et al., 2005), both in relations to direct interactions with plants and with regard to nutrient and organic matter cycling. The microbial biomass of a soil is a comparatively labile pool of soil organic matter (Jenkinson and Ladd, 1981) and can be used as an index of the biological status of the soil fertility. The physical, chemical, and biological properties of soil can be affected by management, fertilization, crops, and the duration of cultivation (Qian et al., 2014). They demonstrated that long-term fertilization, tillage, management regime, leaf litter, and root exudates were the major factors affecting the soil microbial community functions in apple orchard. Shishido et al. (2008) reported that the land-use differences between the apple orchard and its adjacent boundary bush influenced soil microbial activities both quantitatively and qualitatively. Feng et al. (2009) showed that soil microbial biomass was influenced by varying environmental factors including temperature, soil moisture and rainfall. The microbial biomass is responsible for releasing soil enzymes which are essential for catalyzing reactions, necessary for organic matter decomposition and nutrient cycling.

Soil enzymes are involved in most biochemical functions of soil and they are very sensitive to changes in the environment, so they are considered as good indicators to predict changes of soil quality or productivity (Nannipieri et al., 2012). Among the soil enzymes, dehydrogenase activity (DHA) has been recognized as important indicator of the oxidative metabolism in soils and thus of the metabolic activity (Nannipieri et al., 2012), because being exclusively intracellular, it is linked to viable cells. Urease enzyme activity (URE) plays a vital role in the hydrolysis of urea into $\mathrm{CO}_{2}$ and $\mathrm{H}_{2} \mathrm{O}$. Soil phosphomonoesterase (acid and alkaline phosphomonoesterase) activities play an important role in catalyzing the hydrolysis of P-ester bonds binding $\mathrm{P}$ to $\mathrm{C}$ in organic matter, thereby releasing inorganic $\mathrm{P}$ which are assimilable by plants (Pascual et al., 2002). Phosphomonoesterases are concentrated in the surface layer and rhizosphere where most of the fresh and less humified organic matter is prevailing (Asmar et al., 1995). Plants as well as soil microorganisms release acid phosphomonoesterase $\left(\mathrm{A}_{C} \mathrm{PM}\right)$ enzyme in soil however, alkaline phosphomonoesterase $\left(\mathrm{A}_{L} \mathrm{PM}\right)$ enzyme is produced exclusively by soil microorganisms and soil fauna (Chhonkar et al., 2007). Variations in the two phosphomonoesterase activity, apart from indicating changes in the quantity and quality of a 
soil's phosphorated substrates, are good indicator of its biological state (Pascual et al., 2002).

In recent years, studies on microbial biomass and enzymes activity have engaged the attention of many researchers. However, most of these studies are confined to agricultural cropping systems (Wright et al., 2005; Mandal et al., 2007; Jannoura et al., 2013) and forest ecosystems (Barbhuiya et al., 2004; Devi and Yadava, 2006; Feng et al., 2009) but, information regarding those under temperate fruit crops like peach, cherry, apricot, plum etc., are scarce. We assume that soils under temperate fruit crops may be categorized in between agricultural cropping systems and forest systems. Under these crops, the trees are deep rooted, perennial and deciduous in nature. Apart from regular addition of fertilizers and manures, the leaf fall and its incorporation are common which add residues and substrates, thus promoting microbial activity which is expected to be more than field crops. However, soil microorganisms existing in deeper soil depth less strongly influenced by $\mathrm{C}$ inputs from litter and rely partly on root-derived $\mathrm{C}$ for maintaining activity and growth. So, it may be hypothesized that the vertical activity of soil microorganisms would be impacted by root distribution of these fruit crops. Therefore, these orchards constitute a complex ecological landscape. The hypothesis of this experiment was that different temperate fruit crops could have differential microbial activity in the rhizospheric soil (surface and subsurface), influenced by management practice, such as addition of different fertilizers and their levels (on the basis nutritional need of the fruit crops) as well as quality of litter fall and root exudates. For better understanding, we also intended to compare the influence of these fruit crops on microbial activity, with no-plantation system. Thus, the objectives of this experiment were: i) to determine soil microbial biomass $\mathrm{C}, \mathrm{N}$ and $\mathrm{P}$ and their ratio, ii) to assess soil enzyme activities, such as dehydrogenase, phosphomonoesterase (acid and alkaline) and urease and, iii) to study possible correlations among various soil properties, in orchard ecosystem. We assume that information generated from this study will help in understanding of microbially mediated nutrient dynamics and their management under temperate fruit crops in India.

\section{Materials and Methods}

\subsection{Study site}

The experimental orchards are located at Central Institute of Temperate Horticulture (CITH), Srinagar, India ( $34^{\circ} 05^{\prime} \mathrm{N}$ latitude and $74^{\circ} 50^{\prime} \mathrm{E}$ longitude; 1640 $\mathrm{m} \mathrm{msl}$ ). This area falls under arid temperate region, having cold and chilly conditions from November to February, with an average annual rainfall ranges from 600-800 mm. Month-wise (January to May) total precipitation, mean maxima and minima during the year of 2013 are represented in Figure 1a and 1b. The orchards were planted with apricot ( $c v$. Harcot), peach (cv. Fantasia), plum (cv. Santa Rosa) and cherry ( $c v$. CITH Cherry 16) in between 2002-03 and, distributed in an area of half a hectare $(100 \times 50 \mathrm{~m})$ for each. The control plot (no-plantation) of same size, comprising of mainly perennial grasses, has been a fallow land from past 15 years and, has never been fertilized. Hey is used to cut, weighed and removed from the control plot. This practice is carried out twice a year.

All orchards (including control plot) are located within the same geographic area, separated from one other by a space of $7 \mathrm{~m}$. Apricot, peach, plum and cherry trees were planted, with spacing of $2.5 \mathrm{~m}$ (intra-plant) $\times 2.5 \mathrm{~m}$ (between-row); $1.7 \mathrm{~m} \times 1.7 \mathrm{~m} ; 1.5 \mathrm{~m} \times 1.5$ $\mathrm{m}$, and $1.5 \mathrm{~m} \times 1.5 \mathrm{~m}$, respectively. A general layout of the orchards is depicted in Figure 2. The fertilizer doses applied to the fruit crops are $450 \mathrm{~g} \mathrm{~N}$ tree ${ }^{-1}$ for apricot, peach and plum and $300 \mathrm{~g} \mathrm{~N}$ tree $\mathrm{e}^{-1}$ for cherry; 
$150 \mathrm{~g} \mathrm{P}_{2} \mathrm{O}_{5}$ tree $^{-1}$ for apricot, plum and cherry and 390 $\mathrm{g} \mathrm{P}_{2} \mathrm{O}_{5}$ tree $^{-1}$ for peach; $750 \mathrm{~g} \mathrm{~K}_{2} \mathrm{O}$ tree ${ }^{-1}$ for apricot, peach and plum and $440 \mathrm{~g} \mathrm{~K}_{2} \mathrm{O}$ tree $\mathrm{e}^{-1}$ for cherry. One fourth of fertilizer dose is applied to all fruit crops in the first week of February before blossoming and, half dose of fertilizer is applied 15 days after first split. And, rest is applied 25 days after second split. All fruit plants are pruned after leaf-fall, according to standard recommended procedure, during second fortnight of December to maintain canopy area. Farmyard manure (FYM) at the rate of $20 \mathrm{~kg}^{-1} \mathrm{tree}^{-1}$ is added to each fruit crop, immediately after pruning. Plant protection measures are adopted as per recommended management practice, if necessary. The soil of the orchards is ploughed 2-3 times a year, and irrigated as and when required. Manual weeding is practiced throughout the year to keep the orchards weed-free.
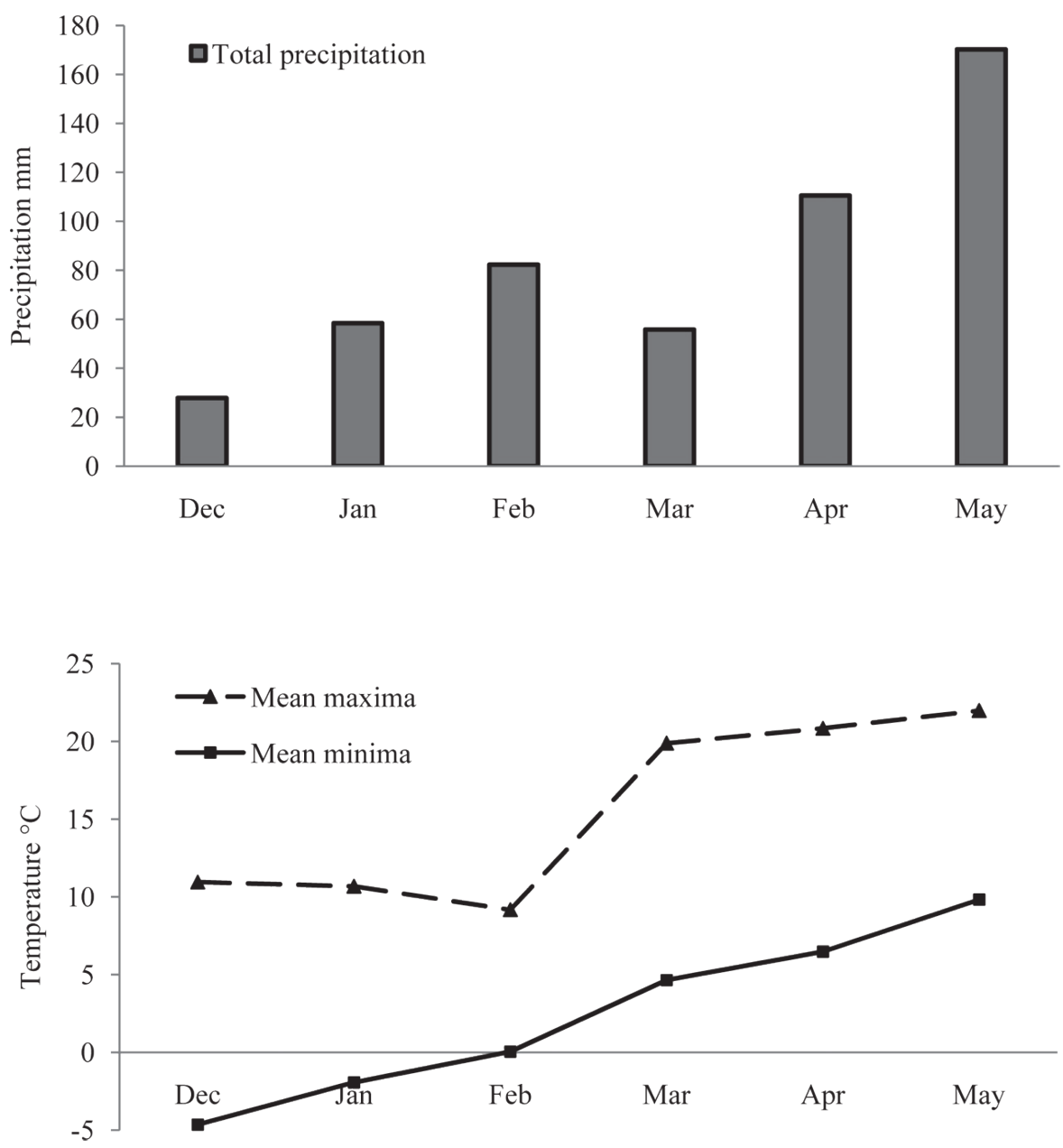

Figure 1. (a) Total precipitation and (b) Mean maxima and minima from January to May of year 2013. The month December indicated in figure is of year 2012. 


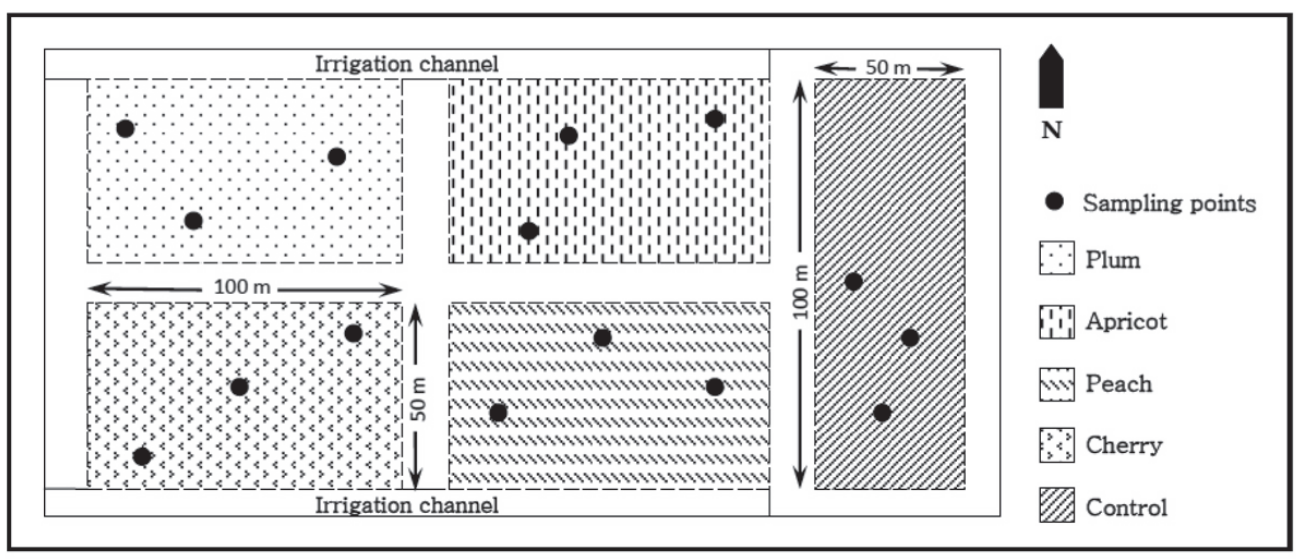

Figure 2. A general layout of the orchards at CITH, Srinagar

\subsection{Soil sampling and analysis}

The volume and distribution of roots in soil is thought to reflect that of the trunk and branches, and moreover the canopy area of the trees. It is often considered as a circular area in soil with trunk at the centre, tantamount to canopy area. Therefore, soil within this area would be a true representative of rhizospheric soil. Soil sampling was performed within this area (just below plant canopy) during the second week of May in 2013, which was around 50-55 days after third split of fertilization. At sampling, all fruit crops were at fruit setting stage, which is considered as an active phase of growth. Soil samples were collected randomly from orchards at two depths: surface (0$20 \mathrm{~cm})$ and subsurface $(21-40 \mathrm{~cm})$ of four temperate fruit crops, viz., apricot, peach, plum and cherry, along with the control (no plantation). Though in microbiological studies sampling thickness uses to be thinner $(0-15 \mathrm{~cm})$, preliminary sampling showed, that more than $90 \%$ of roots were distributed within $45 \mathrm{~cm}$. Therefore, it can be expected that microbial activities would be affected along the depth due to rhizospheric activities. For collecting samples, a trench of $30 \mathrm{~cm}$ wide $\times 40 \mathrm{~cm}$ long $\times 40 \mathrm{~cm}$ deep was dug, from which soil samples were collected with a plastic spatula, from the middle point of each layer from the four sides of the trench. Sub-samples were bulked to make a composite sample (approximately $500 \mathrm{~g}$ ). A total of 30 soil samples ( 5 orchards $\times 2$ depths $\times 3$ replications) were collected, sieved ( $2 \mathrm{~mm}$ mesh) to remove plant tissues and then placed in labeled plastic bags and kept at $4{ }^{\circ} \mathrm{C}$ until further analysis. The gravimetric moisture content was determined immediately. The soil is Inceptisol and classified as Typic Haplustept (USDA Classification), and sandy loam in texture with sand $65 \%$, silt $22 \%$ and clay $13 \%$. Table 1 shows the soil physico-chemical properties of each orchard. 
Table 1. Physico-chemical properties of air dried soil under different temperate fruit crops

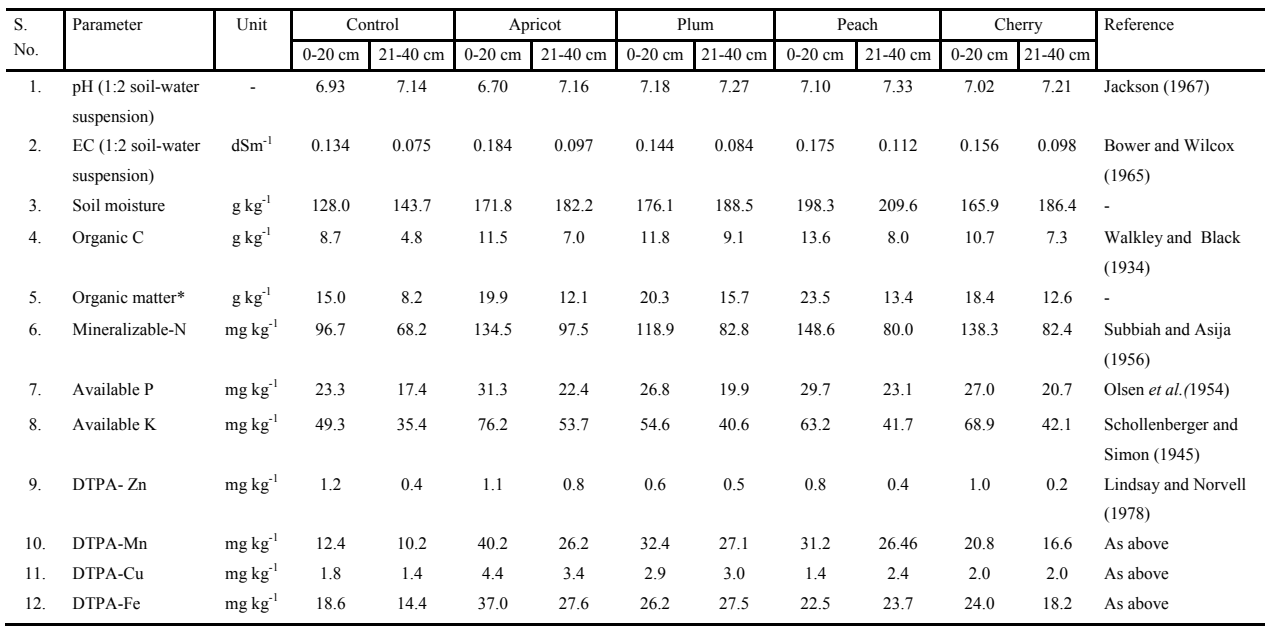

*Organic $\mathrm{C}(\mathrm{OC})$ data were converted to organic matter $(\mathrm{OM})$ using the conventional conversion $\mathrm{OM}=\mathrm{OC} \times 1.724$

\subsubsection{Microbial biomass $\mathrm{C}(\mathrm{MBC})$}

The microbial biomass $\mathrm{C}$ was estimated by chloroform fumigation-extraction method described by Jenkinson and Powlson (1976). The fumigated and non-fumigated soils (equivalent to $10 \mathrm{~g}$ oven-dry soil) were extracted with $0.5 \mathrm{M} \mathrm{K}_{2} \mathrm{SO}_{4}$ solution (1:2.5 soil:extractant ratio) for 30 minutes and filtered. MBC in extract was determined by wet oxidation diffusion method described by Snyder and Trofymow (1984). Five $\mathrm{ml}$ of extract was transferred in diffusion tube and acidified with $0.025 \mathrm{M} \mathrm{H}_{2} \mathrm{SO}_{4}$ and then, digested at $120{ }^{\circ} \mathrm{C}$ for $2 \mathrm{hr}$. The amount of $\mathrm{CO}_{2}-\mathrm{C}$ evolved was trapped in a shell vial (6 $\mathrm{ml}$ capacity) containing 4 $\mathrm{ml}$ of $0.1 \mathrm{~N} \mathrm{NaOH}$ kept over the indentation inside diffusion tube. After digestion, the diffusion tube was allowed to remain undisturbed for $12 \mathrm{hr}$ to ensure complete absorption of evolved $\mathrm{CO}_{2}$-C. After $12 \mathrm{hr}$ the shell vial was taken out of diffusion tube and, the unspent alkali was titrated against $0.02 \mathrm{~N} \mathrm{HCl}$ in presence of an excess of $1 \mathrm{M} \mathrm{BaCl}_{2}$ to stabilize the trapped $\mathrm{CO}_{2}-\mathrm{C}$. An efficiency factor $(\mathrm{Kc})$ of 0.25 was used for calculation of MBC (Bremner and Kesssel, 1990).

\subsubsection{Microbial biomass $\mathrm{N}(\mathrm{MBN})$}

The microbial biomass $\mathrm{N}$ was measured following the fumigation-extraction method described by Brookes et al. (1985). The fumigated and non-fumigated soils (equivalent to $10 \mathrm{~g}$ oven-dry soil) were extracted with $0.5 \mathrm{M} \mathrm{K}_{2} \mathrm{SO}_{4}$ solution (1:4 soil:extractant ratio) for 30 minutes and filtered. Thirty $\mathrm{ml}$ of extract was transferred in digestion tube, and to it $1 \mathrm{ml}$ of $\mathrm{CuSO}_{4}$ $(0.165 \mathrm{M})$ and $10 \mathrm{ml}$ of $\mathrm{H}_{2} \mathrm{SO}_{4}$ (conc.) were added and, the mixture was digested for $3 \mathrm{hr}$ at $390 \pm 2^{\circ} \mathrm{C}$. After digestion, the residue was diluted with distilled water and total $\mathrm{N}$ in it was measured by Kjeldahl method. MBN was calculated using an efficiency factor $(K n)$ of 0.54 (Brookes et al., 1985). 


\subsubsection{Microbial biomass $\mathrm{P}(\mathrm{MBP})$}

The microbial biomass $\mathrm{P}$ was measured using a modified fumigation and $\mathrm{NaHCO}_{3}$ extraction technique (Brookes et al., 1982). Fumigated and non-fumigated soil samples were extracted with $0.5 \mathrm{M} \mathrm{NaHCO}_{3}, \mathrm{pH}$ 8.5 for 30 minutes. In addition, another set of nonfumigated soil, spiked with inorganic-P (equivalent to $25 \mu \mathrm{g} \mathrm{Pi} \mathrm{g}{ }^{-1}$ oven dry soil through $\mathrm{KH}_{2} \mathrm{PO}_{4}$ to estimate per cent recovery of $\mathrm{P}$ from soil), was also extracted with $0.5 \mathrm{M} \mathrm{NaHCO}_{3}$. Prior to filtration phosphate-free charcoal was added to the sample to decolourize the filtrate. The phosphate concentration in the filtrate was measured at $730 \mathrm{~nm}$ by ascorbic acid method described by Murphy and Riley (1962). An efficiency factor $(K \mathrm{p})$ of 0.40 was used to transform the released $\mathrm{P}$ in to microbial biomass $\mathrm{P}$ (Brookes et al., 1982).

\subsubsection{Enzyme activities}

Dehydrogenase activity (DHA) in soil was determined, using the reduction of 2,3,5-triphenyltetrazolium chloride (3\%) method (Klein et al., 1971), and the colour intensity was measured at $485 \mathrm{~nm}$. The method used for estimating urease activity (URE), involved incubating the soil with an aqueous urea solution (2\%), and the residual urea was determined colorimetrically at $527 \mathrm{~nm}$, described by Bremner and Douglas (1981). Acid $\left(\mathrm{A}_{C} \mathrm{PM}\right)$ and alkaline $\left(\mathrm{A}_{L} \mathrm{PM}\right)$ phosphomonoesterase activities were estimated following the method reported by Tabatabai and Bremner (1969), after soil incubation with modified universal buffer (MUB, adjusted to $\mathrm{pH} 6.5$ for acid phosphomonoesterase and $\mathrm{pH} 11.0$ for alkaline phosphomonoesterase) and p-nitrophenyl phosphate (pH 6.5 and 11.0 for acid and alkaline phosphomonoesterse, respectively), and the produced colour intensity was measured colorimetrically at $440 \mathrm{~nm}$.

\subsection{Statistical analysis}

One way analysis of variance (ANOVA) was performed to elucidate the effect of different temperate fruit crops and soil depths on the soil biological properties. Statistical analysis of the data was carried out in accordance with the procedure suggested by Gomez and Gomez (1984). Duncan's multiple range test (DMRT) and LSD at $p<0.05$ for comparison of significant differences between means, have been performed using SPSS 16.0 (SPSS Inc., Chicago, USA) windows version package. Simple correlations (Pearson) were worked out between soil physico-chemical and microbiological properties to show their degree of associations.

\section{Results}

\subsection{Microbial biomass $C$ (MBC)}

All fruit crops including control have shown higher $\mathrm{MBC}$ on the surface layer compared to subsurface layer (Table 2) and, they were also significant over control in both layers. MBC was also found to be significant between the soil layers of same type of fruit crop. It is clearly seen from the table that maximum MBC was recorded in plum (1000 $\mathrm{mg} \mathrm{kg}^{-1)}$ followed by peach $\left(928 \mathrm{mg} \mathrm{kg}^{-1}\right)$ and apricot $\left(852 \mathrm{mg} \mathrm{kg}^{-1}\right)$, and the lowest was observed in control $\left(457 \mathrm{mg} \mathrm{kg}^{-1}\right)$, at the surface layer.

The same is followed also in the subsurface layer for all orchards. From table, the MBC obtained in both layers can be arranged in a descending order as: plum $>$ peach $>$ apricot $>$ cherry $>$ control. 
Table 2. Microbial biomass carbon, nitrogen and phosphorus in the orchard soil of different temperate fruit crops, at two depths

\begin{tabular}{|c|c|c|c|c|}
\hline Fruit crops & & Surface soil $(0-20 \mathrm{~cm})$ & Subsurface soil $(21-40 \mathrm{~cm})$ & Between layers $^{\dagger}$ \\
\hline & $\mathrm{MBC}\left(\mathrm{mg} \mathrm{kg}^{-1}\right)$ & & & \\
\hline Control & & 457 (a) & 307 (a) & ns \\
\hline Apricot & & 852 (b) & $592(b)$ & $*$ \\
\hline Plum & & 1000 (b) & $692(b)$ & $*$ \\
\hline Peach & & 928 (b) & $684(b)$ & $*$ \\
\hline Cherry & & 825 (b) & $513(b)$ & $*$ \\
\hline \multirow[t]{2}{*}{ Mean } & & 812 & 558 & \\
\hline & $\operatorname{MBN}\left(\mathrm{mg} \mathrm{kg}^{-1}\right)$ & & & \\
\hline Control & & 180 (a) & 101 (a) & $*$ \\
\hline Apricot & & 242 (a) & $138(a)$ & $*$ \\
\hline Plum & & $320(b)$ & $156(a)$ & $*$ \\
\hline Peach & & 278 (b) & 142 (a) & $*$ \\
\hline Cherry & & 181 (a) & 104 (a) & $*$ \\
\hline \multirow[t]{2}{*}{ Mean } & & 240 & 128 & \\
\hline & $\operatorname{MBP}\left(\mathrm{mg} \mathrm{kg}^{-1}\right)$ & & & \\
\hline Control & & 48 (a) & 37 (a) & ns \\
\hline Apricot & & 63 (a) & 47 (a) & $\mathrm{ns}$ \\
\hline Plum & & 51 (a) & 42 (a) & ns \\
\hline Peach & & $92(b)$ & 67 (a) & ns \\
\hline Cherry & & $56(a)$ & 46 (a) & ns \\
\hline$\cdots$ & & - & $\ldots$ & \\
\hline
\end{tabular}

MBC - microbial biomass carbon, MBN - microbial biomass nitrogen, MBP - microbial biomass phosphorus. Values followed by different alphabets in parenthesis are significantly different at $p<0.05$ based on Duncan's multiple range test (DMRT).

${ }^{\dagger}$ Significance between soil layers of same fruit crop at $p<0.05$, ns: non significant.

\subsection{Microbial biomass $N(M B N)$}

Data on MBN in soil samples showed a significant effect at the surface layer for peach and plum (Table 2). None of the fruit crops were found to be statistically significant over control, at the subsurface layer. Nonetheless, MBN was significant between the soil layers of same type of fruit crop. Like MBC, the surface soil has shown higher MBN than subsurface soil. From the table it can be inferred that surface soil layer of plum had the maximum MBN (320 mg kg-1) followed by peach $\left(278 \mathrm{mg} \mathrm{kg}^{-1}\right)$ and apricot $(242 \mathrm{mg}$ $\mathrm{kg}^{-1}$ ), and the same trend also followed at the subsurface layer, like $\mathrm{MBC}$. With regard to $\mathrm{MBC} / \mathrm{MBN}$ ratio, there was no significant effect of the fruit crops in both the soil depths, except for peach in surface layer (Table 3). The ratio showed a sharp increase in subsoil over surface layer. The highest ratio was obtained in cherry (5.2) and the lowest in the control (3.2), at the subsurface layer. 
Table 3. Ratio of microbial biomass in the orchard soil of different temperate fruit crops, at two depths

\begin{tabular}{|c|c|c|c|c|}
\hline Fruit crops & & Surface soil $(0-20 \mathrm{~cm})$ & Subsurface soil $(21-40 \mathrm{~cm})$ & Between layers $^{\dagger}$ \\
\hline & $\mathrm{MBC} / \mathrm{MBN}$ & & & \\
\hline Control & & 2.61 (a) & 3.24 (a) & $\mathrm{ns}$ \\
\hline Apricot & & 3.55 (a) & 4.50 (a) & ns \\
\hline Plum & & 3.27 (a) & 4.53 (a) & ns \\
\hline Peach & & 3.46 (b) & 5.12 (a) & $*$ \\
\hline Cherry & & 4.64 (a) & 5.22 (a) & ns \\
\hline \multirow[t]{2}{*}{ Mean } & & 3.50 & 4.52 (a) & \\
\hline & $\mathrm{MBC} / \mathrm{MBP}$ & & & \\
\hline Control & & 9.94 (a) & 8.42 (a) & ns \\
\hline Apricot & & 13.78 (a) & 15.67 (a) & ns \\
\hline Plum & & $20.80(b)$ & $19.26(b)$ & ns \\
\hline Peach & & 10.24 (a) & 10.63 (a) & ns \\
\hline Cherry & & 15.23 (a) & 11.23 (a) & ns \\
\hline \multirow[t]{2}{*}{ Mean } & & 14.01 & 13.04 & \\
\hline & $\mathrm{MBN} / \mathrm{MBP}$ & & & \\
\hline Control & & 3.90 (a) & 2.81 (a) & ns \\
\hline Apricot & & 3.86 (a) & 3.27 (a) & ns \\
\hline Plum & & $6.42(b)$ & 4.55 (a) & ns \\
\hline Peach & & 3.12 (a) & 2.14 (a) & ns \\
\hline Cherry & & 3.27 (a) & 2.34 (a) & ns \\
\hline Mean & & 4.12 & 3.02 (a) & \\
\hline
\end{tabular}

MBC - microbial biomass carbon, MBN - microbial biomass nitrogen, MBP - microbial biomass phosphorus. Values followed by different alphabets in parenthesis are significantly different at $p<0.05$ based on Duncan's multiple range test (DMRT).

$\dagger$ Significance between soil layers of same fruit crop at $p<0.05$, ns: non significant.

\subsection{Microbial biomass $P(M B P)$}

Like MBC and MBN, the values of MBP also decreased with soil depth (Table 2). Highest MBP was observed in peach $\left(92 \mathrm{mg} \mathrm{kg}^{-1}\right)$ followed by apricot (63 $\mathrm{mg} \mathrm{kg}^{-1}$ ) and cherry (56 $\left.\mathrm{mg} \mathrm{kg}^{-1}\right)$, at the surface layer and the same also followed in the subsurface layer. From the table MBP for both soil depths can be arranged in a descending order as: peach $>$ aprico $\mathrm{t}>$ cherry $>$ plum $>$ control. The fruit crops showed any significant effect neither on surface nor, on subsurface soil layer except for peach, where MBP of surface layer was significantly varied over the control. The MBC/MBP ratio ranged from 8.4 (control) to 20.8 (plum). An inconsistent trend of the ratio was observed between soil depths and fruit crops (Table 3). For some fruit crops it decreased with soil depth, while for others an opposite phenomenon was observed. Except 
plum, the fruit crops did not show any significance compared to control in both soil depths. With respect to $\mathrm{MBN} / \mathrm{MBP}$ ratio, only plum had significant effect over control at surface soil. The ratio decreased with soil depth for all fruit crops, contrary to what was observed in case of MBC/MBN (Table 3).

\subsection{Dehydrogenase activity (DHA)}

Like microbial biomass, DHA was also found to be higher in surface soil and declined with soil depth (Figure 3a). At surface layer, the maximum DHA was observed in peach $\left(318 \mu \mathrm{g}\right.$ TPF $\left.\mathrm{g} \mathrm{soil}^{-1} \mathrm{~h}^{-1}\right)$ and, the lowest value $\left(166 \mu \mathrm{g}\right.$ TPF $\mathrm{g}$ soil $\left.^{-1} \mathrm{~h}^{-1}\right)$ was attained at control plot. The descending order of the DHA observed in surface soil layer can be represented as: peach $>$ plum $>$ apricot $>$ cherry $>$ control. However, the same trend was not followed in subsoil. At surface layer, only peach and cherry showed significant effect on DHA over control, although all of the fruit crops failed to influence DHA in subsoil layer. Nonetheless, DHA was significant between the soil layers of same type of fruit crop.
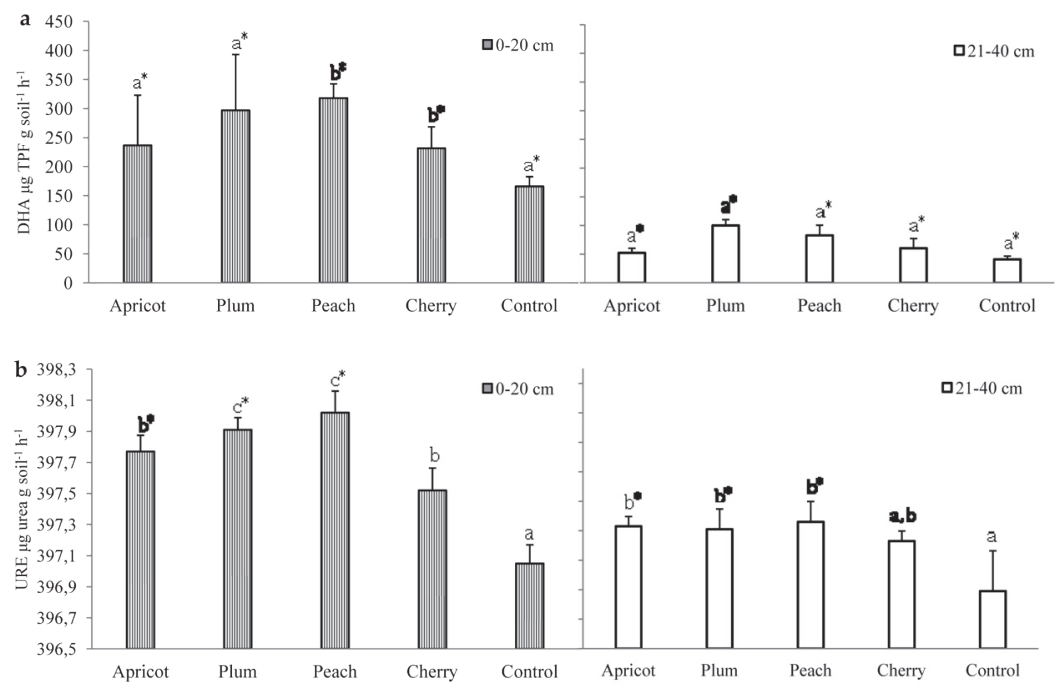

Figure 3. (a) Dehydrogenase activity (DHA) and (b) Urease activity (URE) in soil at two depths of different temperate fruit crops. Bars indicate standard errors $(n=3)$. Means not sharing a letter in common differ significantly $(p<0.05)$ between same soil layers of different fruit crops. Means sharing ' $*$ ' in common differ significantly $(p<0.05)$ between soil layers of same fruit crop.

\subsection{Urease activity (URE)}

Like microbial biomass and other enzyme activities, URE was also found to be higher in surface layer compared to subsurface layer, in all orchards (Figure 3b). During this study, peach was found to have highest URE (398.02 $\mu \mathrm{g}$ urea $\mathrm{g}$ soil $^{-1} \mathrm{~h}^{-1)}$ followed by plum $\left(397.91 \mu \mathrm{g}\right.$ urea $\mathrm{g}$ soil $\left.^{-1} \mathrm{~h}^{-1}\right)$ and apricot $(397.78$ $\mu \mathrm{g}$ urea $\left.\mathrm{g} \mathrm{soil}^{-1} \mathrm{~h}^{-1}\right)$, and least value was observed 
for control, at the surface layer. All fruit crops had significant effect on URE over control in surface soil. Except cherry, URE was also found to be significant between the soil layers of same type of fruit crop.

\subsection{Phosphomonoesterase activity}

Activity of phosphomonoesterase is important in studying the $\mathrm{P}$ cycle because they provide avenue for $\mathrm{P}$ mineralization. Like DHA, the activity of both phosphomonoesterases was found to be higher in surface layer compared to subsurface layer in all orchards (Figure $4 \mathrm{a}$ and $4 \mathrm{~b}$ ). The trend of activity of the two phosphomonoesterases was not similar for the fruit crops under investigation. They varied differently among the fruit crops and, sometimes even contrasting, particularly at subsurface soil. Maximum $\mathrm{A}_{L} \mathrm{PM}$ was observed in peach $\left(391 \mu \mathrm{g}\right.$ PNP $\mathrm{g}$ soil $^{-1}$ $\left.\mathrm{h}^{-1}\right)$ and, the lowest value found in control $(198 \mu \mathrm{g}$ PNP g soil ${ }^{-1} \mathrm{~h}^{-1}$ ) at surface layer. At subsurface layer, the highest value for the same enzyme was also recorded in peach (299 $\mu \mathrm{g}$ PNP g soil- $\left.{ }^{-1} \mathrm{~h}^{-1}\right)$. The fruit crops showed significant effect on $\mathrm{A}_{L} \mathrm{PM}$ compared to control between same soil layers of different fruit crops. Unlike $\mathrm{A}_{L} \mathrm{PM}, \mathrm{A}_{C} \mathrm{PM}$ was reported highest in apricot (308 $\mu \mathrm{g}$ PNP g soil $\left.{ }^{-1} \mathrm{~h}^{-1}\right)$ at surface soil, and lowest value obtained in control at both layers (Figure 4b). All fruit crops, except plum, had significant effect on $\mathrm{A}_{C} \mathrm{PM}$ over control in the surface soil. However, $\mathrm{A}_{C} \mathrm{PM}$ was significant between the soil layers of same type of fruit crop.

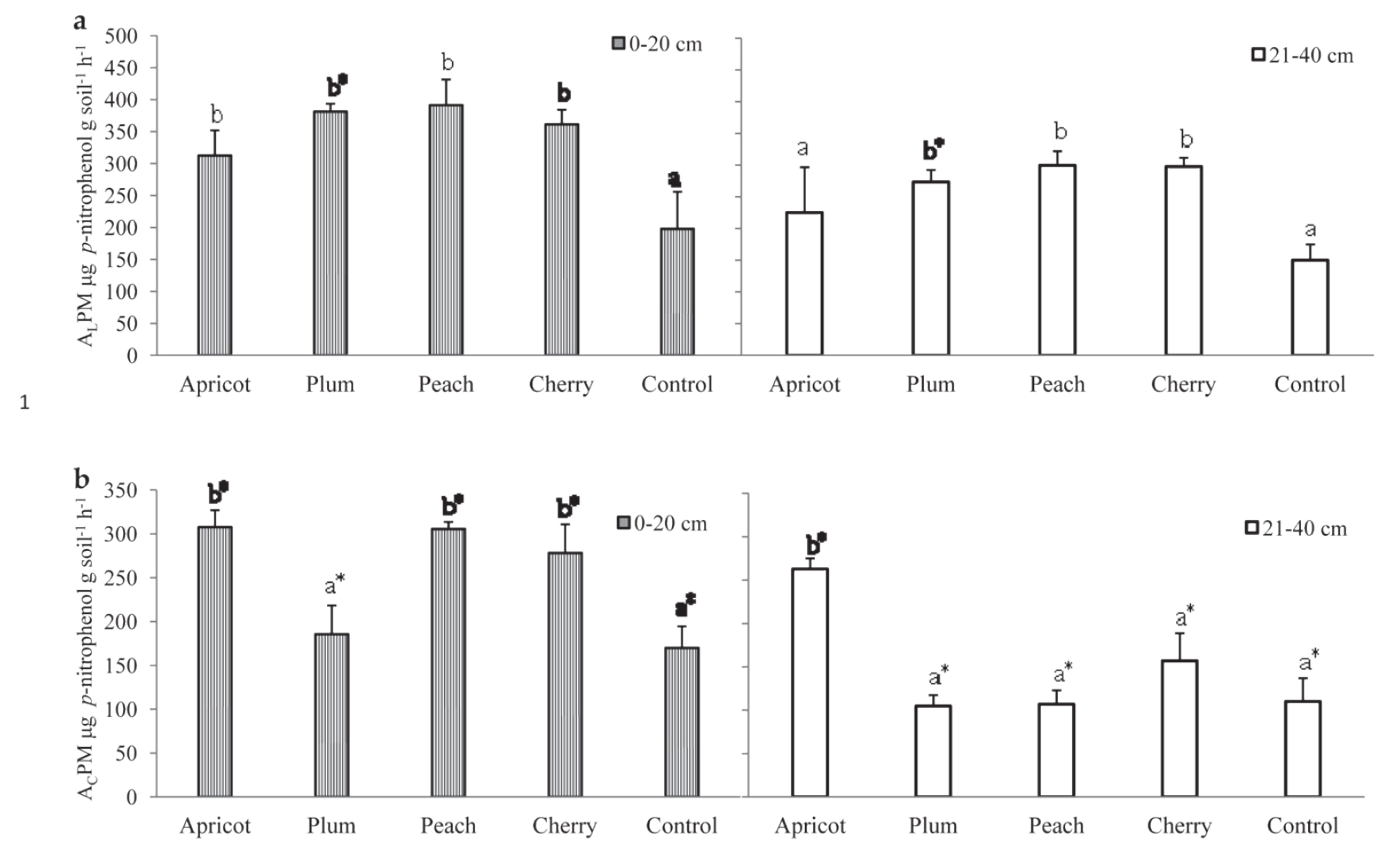

Figure 4. (a) Alkaline phosphomonoesterase activity $\left(A_{L} P M\right)$ and (b) Acid phosphomonoesterase activity $\left(A_{C} P M\right)$ in soil at two depths of different temperate fruit crops. Bars indicate standard errors $(n=3)$. Means not sharing a letter in common differ significantly $(p<0.05)$ between same soil layers of different fruit crops. Means sharing ' $*$, in common differ significantly $(p<0.05)$ between soil layers of same fruit crop. 


\subsection{Correlation studies}

Correlation study (Table 4) has shown the existence of significant relationship between the DHA and $\mathrm{A}_{L} \mathrm{PM}$ activity $(\mathrm{r}=0.588, p<0.01)$, and the two phosphomonoesterase enzymes activity $(\mathrm{r}=0.483, p$ $<0.01)$. It was also evident from the correlation study that DHA significantly correlated with $\mathrm{MBC}(\mathrm{r}=0.687$, $p<0.05$ ). All kind of microbial biomass and enzyme activities were found to be significantly correlated with both organic $\mathrm{C}$ and organic matter. A positive significant relationship between $\mathrm{MBC}$ and $\mathrm{MBN}$ to $\mathrm{A}_{C} \mathrm{PM}(\mathrm{r}=0.497, p<0.01)$ and $\mathrm{A}_{L} \mathrm{PM}(\mathrm{r}=0.557, p$ $<0.01$ ), respectively was observed. Significant positive correlations were also observed between microbial biomass $\mathrm{C}, \mathrm{N}$ and $\mathrm{P}$. Both the phosphomonoesterase activities were significantly $(p<0.05)$ correlated with MBP and available P in soil. However, a weak and non-significant relation was obtained between these two enzymes and soil pH. URE activity was also strongly correlated with mineralizable- $\mathrm{N}$ content $(\mathrm{r}=$ 0.823, $p<0.05$ ) of soil. Microbial biomass $\mathrm{C}$ was found to be positively correlated with soil moisture $(\mathrm{r}=0.519, p<0.05)$, mineralizable-N $(\mathrm{r}=0.567, p$ $<0.01)$ and available $\mathrm{P}(\mathrm{r}=0.648, p<0.01)$. Similar kind of result was also recorded in case of MBN. A non-significant relationship was observed between MBP and available P.

\section{Discussion}

The significant difference in $\mathrm{MBC}$ and $\mathrm{MBN}$ between the soil layers of same fruit crop was expected. However, Wright et al. (2005) reported non-significant values of microbial biomass $\mathrm{C}$ and $\mathrm{N}$ between different soil depths within plough layer $(0-20 \mathrm{~cm})$ in field crops. We hypothesized that the activity of soil microorganisms would be affected by the fruit crops along the selected soil depths.
The observed results support our hypothesis. These results suggest that microbial activity in surface soil was perhaps influenced by the inputs added as well as litter-fall whereas, root exudates and other root related activities were probably the principal governor of microbial activity in subsurface soil. The values of MBC observed are well within the range, as reported by many authors under orchard system (Dinesh et al., 2006; Peck et al., 2011) and forest system (Barbhuiya et al., 2004; Devi and Yadava, 2006). However, these values are much higher compared to agricultural cropping system (Manna et al., 2005; Mandal et al., 2007). Generally, microbial biomass $C$ constitutes about $1-5 \%$ of soil organic C (Jenkinson and Ladd, 1981), but variation within this range is particularly influenced by the quantity and quality of organic matter inputs to the soil. Its shift may indicate the changes in soil microorganism activity. The greater MBC content of the orchards could be attributed to the accumulation of organic matter. In other words, the increase in the size of microbial community was proportional to the increased organic matter content of the soil. In addition to organic matter, some other factors also influenced MBC in soil. In this study, soil moisture varied to a great extent among the orchards, which could be ascribed to variations in soil organic matter content. It can be expected that different fruit crops would have differential water requirement. And, that may be another reason that samples showed differences in terms of soil moisture. The positive significant correlation between MBC and soil moisture indicated that soil water content affect soil microbial populations (Table 4). Several studies on soil microbial biomass reported a close relationship between soil moisture and microbial biomass (Devi and Yadava, 2006; Feng et al., 2009), which are in conformity with our observation. At sampling, the mean maximum air temperature was around $22{ }^{\circ} \mathrm{C}$ (Figure 1b). The temperature in the 
surface layer of soil is generally higher than the air temperature and, soils under tree canopy may remain at a uniform temperature in surface layer. Therefore, it can be suggested that soil temperature was suitable for enhanced microbial activity, particularly the activity of mesophilic organisms. Thus, temperature perhaps also played a key role in this study to increase the values of MBC. The declining trend of MBC with depth suggests that a great fraction of the soil microbial community is colonizing the surface soil. This might be due to the fact that, with increasing depth soil organic matter decreased, thereby microbial activity. Since there is a strong relationship between MBC and MBN (Table 4), the results discussed for variable amounts of $\mathrm{MBC}$ recorded in this study are somewhat applicable to MBN, as well. The increase in the values of MBN might be because of more plant organic residues, and root biomass production were likely to return to soil, which was also reflected in the mineralizable-N content of the soil (Table 1). The age of the fruit orchards could also affect MBN. This could be attributed to the fact that, soil organic matter content increases gradually with time, particularly under temperate condition, where the stability of soil organic matter is relatively more. In other words, the higher MBN in soil was likely due to the relatively high proportion of organic matter from litter inputs, and root exudates being available to support microbial activity with time. This finding is similar with Jia et al. (2010) who reported that the age of shrub plantation had profound influence on MBN content of soil. Microbial biomass $\mathrm{P}$ values are well within the reported range (5-67 $\mathrm{mg} \mathrm{kg}^{-1}$ ) for the agricultural land, grassland, orchard and woodland soils (Brookes et al., 1984; Dinesh et al., 2006). The non-significant influence of the fruit crops on MBP could perhaps be due to low availability of $\mathrm{P}$ in soil for microbial immobilization. At the time of sampling, the fruit crops were at fruit setting stage which is considered as an active growth phase. Relatively greater demand for nutrients by plants during this phase could have limited the availability of $\mathrm{P}$ to soil microbes, thereby reducing its mobilization to microbial biomass.

The ratio of microbial biomass $\mathrm{C}, \mathrm{N}$ and $\mathrm{P}$ in soil might serve as a quantitative indicator of availability and dynamics of these elements. The higher microbial biomass $\mathrm{C} / \mathrm{N}$ ratio in subsurface soil layer than in surface layer was mainly due to lower microbial biomass $\mathrm{N}$ in the former or, due to greater decrease in MBC compared to MBN (Barbhuiya et al., 2004; Jenkinson and Ladd, 1981). This was perhaps also due to low $\mathrm{N}$ availability and, relatively higher organic matter availability to soil microbes at deeper soil depth. The observed microbial $\mathrm{C} / \mathrm{N}$ ratio in this present study was less than $6 . \mathrm{C}: \mathrm{N}$ ratio of fungal hyphae usually ranges from 10 to 12 , and that of bacteria 3 to 5 (Jenkinson and Ladd, 1981). Therefore, it could be stated that the study site might have been dominated by bacterial community. Perhaps this could be attributed to preferential stimulation of bacterial community due to varying composition of root exudates, leading to selective favoring of those organisms. It may also be stated that neutral soil $\mathrm{pH}$ of the orchards is suitable for bacterial activity. It is also possible that as well as differences in microbial biomass, differences in the composition of the microbial community between orchards might have occurred. The MBC/MBP ratio for all fruit crops in our study falls well within the reported range of 10.6 to 35.9 (Brookes et al., 1984). The inconsistent variations in biomass $\mathrm{C} / \mathrm{P}$ ratio within soil depth indicate that $\mathrm{P}$ in microbial cell was affected by the soil conditions and type of fruit crops. The reduced significance of biomass $\mathrm{C} / \mathrm{P}$ ratio was probably also due to the same reason. Phosphorus is considered as an important constituent of microbial cell. Thus, in this soil, there is a diversity of soil microbes having different biomass $\mathrm{P}$ requirement. Future studies 
may reveal the differences in the composition of the microbial community in the soil profile of these orchards. In this study MBP and MBC/MBP ratio were markedly affected by high $\mathrm{P}$ bioavailability (Table 1). Low $\mathrm{P}$ and high $\mathrm{C}$ availability results in large biomass $\mathrm{C} / \mathrm{P}$ ratios and vice-versa. The low mean $\mathrm{MBC} / \mathrm{MBP}$ ratio in our study with its high contents of available
$\mathrm{P}$ supports this. The decrease in microbial biomass $\mathrm{N} / \mathrm{P}$ ratio with soil depth was probably due to low $\mathrm{N}$ availability or, due to greater decrease in biomass $\mathrm{N}$ compared to $\mathrm{P}$ in subsurface soil. This could be again attributed to the demand for nutrients by the fruit crops at the time of sampling, which perhaps limited the availability of $\mathrm{N}$ to soil microorganisms.

Table 4. Pearson's correlation coefficient ( $\mathrm{r}$ values) of variables related to various soil properties

\begin{tabular}{|c|c|c|c|c|c|c|c|c|c|c|c|c|c|c|}
\hline & A & $B$ & C & $D$ & E & $F$ & $G$ & $H$ & $I$ & $J$ & K & $L$ & $M$ & $N$ \\
\hline$A$ & 1 & & & & & & & & & & & & & \\
\hline$B$ & 0.588 (a) & 1 & & & & & & & & & & & & \\
\hline C & 0.760 & 0.483 (a) & 1 & & & & & & & & & & & \\
\hline$D$ & 0.609 & 0.726 & 0.482 & 1 & & & & & & & & & & \\
\hline E & 0.687 (b) & 0.689 & 0.497 (a) & 0.793 & 1 & & & & & & & & & \\
\hline$F$ & 0.790 & 0.557 (a) & 0.661 & 0.635 & 0.580 (a) & 1 & & & & & & & & \\
\hline G & 0.458 (b) & 0.408 (b) & 0.358 (b) & 0.546 (a) & 0.413 (b) & 0.581 (a) & 1 & & & & & & & \\
\hline$H$ & -0.330 & 0.061 & 0.115 & -0.157 & -0.116 & -0.390 (a) & -0.013 & 1 & & & & & & \\
\hline$I$ & 0.871 (a) & 0.586 (a) & 0.745 (a) & 0.738 (a) & 0.660 (a) & 0.799 (a) & 0.578 (a) & $-0.516(a)$ & 1 & & & & & \\
\hline$J$ & -0.288 & -0.152 & $-0.486(a)$ & 0.063 & $0.519(b)$ & 0.124 (a) & 0.288 & 0.249 & -0.129 & 1 & & & & \\
\hline K & 0.736 (a) & 0.679 (a) & 0.574 (a) & 0.861 (a) & 0.771 (a) & 0.705 (a) & 0.521 (a) & -0.296 & $0.816(\mathrm{a})$ & -0.058 & 1 & & & \\
\hline$L$ & 0.737 (a) & 0.685 (a) & 0.567 (a) & 0.861 (a) & 0.778 (a) & 0.701 (a) & 0.534 (a) & -0.291 & $0.816(\mathrm{a})$ & -0.058 & 0.991 (a) & 1 & & \\
\hline M & 0.506 (b) & 0.523 & 0.481 & $0.823(b)$ & 0.567 (a) & $0.652(b)$ & 0.423 & -0.338 & 0.259 (a) & -0.238 & 0.689 (a) & 0.994(a) & 1 & \\
\hline$N$ & 0.487 (b) & 0.889 (b) & 0.741 (a) & 0.772 & 0.648 (a) & 0.705 (b) & 0.526 & -0.267 & 0.437 (a) & -0.497 & $0.865(\mathrm{~b})$ & $0.878(a)$ & 0.138 & 1 \\
\hline
\end{tabular}

$A$ - dehydrogenase activity, $B$ and $C$ - phosphomonoesterase activity (alkaline and acid, respectively), $D$ - urease activity, $E$ - microbial biomass carbon, $F$ - microbial biomass nitrogen, $G$ - microbial biomass phosphorus, $H$ - soil $\mathrm{pH}, I$ - electrical conductivity, $J$ - soil moisture, $K$ - organic $\mathrm{C}, L$ - organic matter, $M$ - mineralizable $\mathrm{N}, N$-available $\mathrm{P}$

(a) Significant at $p=0.01$ (b) Significant at $p=0.05$

DHA in soil depends on the content of soluble organic carbon and, the increased organic matter in the surface soil enhances the soil enzyme activities (Nannipieri et al., 2012). The major reason for increased DHA in the surface soil could be attributed to the greater availability of soluble organic $\mathrm{C}$, nutrients and, stimulated microbial activity. This result is in agreement with the observation made by Adak et al. (2014) in mango orchard. The stimulation of DHA could also be due to improvement in other living conditions like moisture, temperature etc. Such observation may be also due to influence of litter-fall, inputs (e.g. fertilizers, organic manures etc.) and, cultural practices such as tillage, irrigation etc. In the deeper layer the effect of above factors is expected 
to be reduced. Significant difference in DHA between soil layers of same fruit crop might be primarily due to rhizospheric effect of the fruit crops. Quantitative and qualitative differences in root exudation by various fruit crops might indirectly influenced dissimilar proliferation of soil microbial species, responsible for mineralization of organic $\mathrm{P}$ through release of phosphomonoesterase. The inconsistent variations in the trend of activity of the two phosphomonoesterase enzymes could be supported by this. Phosphomonoesterases are mainly concentrated in the surface layer, and our result confirms this observation. Alkaline phosphomonoesterase ( $\left.\mathrm{A}_{L} \mathrm{PM}\right)$ activity is derived from microorganisms only, while acid phosphomonoesterase $\left(\mathrm{A}_{C} \mathrm{PM}\right)$ is contributed both by plant roots and soil-inhabiting microbes (Chhonkar et al., 2007). George et al. (2002) reported a higher rhizospheric phosphatase activity in some agroforestry species either directly by secretion or, indirectly by stimulation of microbial activity and/or depletion of inorganic P. As discussed, higher $\mathrm{P}$ requirement of the fruit crops at sampling, perhaps limited immobilization of available $\mathrm{P}$ to soil microbes. This probably triggered the soil microorganisms to release more of $\mathrm{A}_{L} \mathrm{PM}$ in soil to mineralize organically bound P. Our data suggested that phosphomonoesterases originating from either plant roots or, microorganisms had the potential for enhancing $\mathrm{P}$ availability. Alkaline reaction of the soil might also have increased $\mathrm{A}_{L} \mathrm{PM}$ activity over $\mathrm{A}_{C} \mathrm{PM}$. The $\mathrm{pH}$ of the soil solution exerts a strong control on these enzyme activities (Chhonkar et al., 2007). The pH-dependence of these enzymes could be due to the influence of soil $\mathrm{pH}$ on the concentration of inhibitors or activators in the soil solution and the effective concentration of the substrate (Dick et al., 2000). Urease activity (URE) recorded in this experiment was quite higher. Higher microbial activity, as indicated by microbial biomass, in soil could have enhanced the values of URE to such extent. Increased activity of URE also resulted in an increase in mineralizable-N content of the soil (Table 1). Moreover, mineralizable-N content of the soil declined from surface to subsurface like URE. Thus, it could be suggested that $\mathrm{N}$ supply to the fruit crops was regulated by this enzyme.

Significant positive correlations between microbial biomass $\mathrm{C}, \mathrm{N}$ and $\mathrm{P}$ indicate that the dynamics of these three elements are closely interlinked in the soil of these orchards. Under field conditions, microbial and enzyme activities depend more on the type of crop and, are stimulated by organic matter. Soil organic C plays a key role as a precursor for enzyme synthesis and, also as a substrate source for enzyme activity during mineralization. Thus, activity of soil enzymes has a strong relationship with soil organic C. A similar kind of observation is also recorded in our study. DHA in soil is considered to be a good indicator of microbial activity and its significant correlation with MBC is obvious (Jenkinson and Ladd, 1981). The strong relationship between the two phosphomonoesterase enzymes was expected, since these enzymes regulate $\mathrm{P}$ cycle and provide route for $\mathrm{P}$ mineralization in soil. Significant correlation of these enzymes with available P and MBP indicate that dynamics of soil $\mathrm{P}$ was governed by these enzymes to a great extent. The soil microbes have two main roles in the dynamics of $\mathrm{P}$ in soil: i) the principal driver for the transformation of organically bound phosphorus to plant available phosphate, and ii) the accumulator of a significant pool of $\mathrm{P}$ (Damon et al., 2014). The non-significant correlation between phosphomonoesterase enzymes and soil $\mathrm{pH}$ could be attributed to inconsistent variations of activity in former within soil depth. Therefore, our results do not conform to the findings reported by many authors (Dick et al., 2000). It could also be due to the fact that $\mathrm{pH}$ increased while phosphomonoesterase enzymes 
activity decreased, with soil depth. In fact, weak and negative correlation between $\mathrm{pH}$ and majority of soil microbiological properties was perhaps also due to the same reason. This also elucidates that soil $\mathrm{pH}$ had very little influence on microbiological properties of the selected orchards. The significant relationship between $\mathrm{MBC}$ and $\mathrm{A}_{C} \mathrm{PM} ; \mathrm{MBN}$ and $\mathrm{A}_{L} \mathrm{PM}$ were not clear, perhaps soil organic matter played a vital role in this regard which enhanced $\mathrm{MBC}$ and $\mathrm{MBN}$, leading to increased enzymatic activities. Like MBC, it seems that soil moisture had also a strong influence on the dynamics of MBN. URE in soil plays a vital role in the regulation of $\mathrm{N}$ supply to plant and its uptake. The significant positive correlation between URE and mineralizable-N is in agreement with this. The relationship between MBP and URE was interesting to notice, and the reason behind this could not be recognized from this single study. Positive correlations between microbial biomass and available nutrient status like N, P suggested that the orchards supported continuous recycling of litter-fall, root exudates and, improved microbiological transformation of nutrients into available form.

\section{Conclusions}

It can be concluded that microbial biomass and enzyme activities were strongly influenced by the type of fruit crops of Kashmir valley region of NWHR. The different response of microbial biomass and enzyme activities between the orchards and control plot soils observed in this study could support our hypothesis. Despite deep rooted nature of these fruit crops, microbial biomass and enzymatic activities declined with increase in soil depth. Thus, whether it is fruit crops or field crops, the behavior of the microbial activities remains unaltered, and more over most of the microbial activities are concentrated within surface soil $(0-20 \mathrm{~cm})$. Only difference between these systems may be the intensity of the activities which was reflected in this study. Ratios of microbial biomass indicated the relative availability of $\mathrm{C}, \mathrm{N}$ and $\mathrm{P}$ for microbial immobilization. However, determination of these ratios during the entire crop growth period is needed to gain more information regarding nutrient availability to soil microbes. Significant differences in microbial biomass $\mathrm{C}$ and $\mathrm{N}$ and enzyme activities between the soil layers of same fruit crop also revealed in this study. One of the major reasons of such differences may be due to inputs added to the particular fruit crop and other management practices like tillage, irrigation etc., as well as litter-fall. Another reason is extent to addition of root and other residues and their interactions with soil microbes. Quality and quantity of leaf litters of the fruit trees and below ground microbial diversity needs to be studied in future to unravel the reasons of variable microbial indicators and soil quality.

\section{Acknowledgements}

This research work was carried out under 'Professional Attachment Training' as a part of the revised module of FOCARS training, and for that the authors are thankful to Indian Council of Agricultural Research (ICAR). The first author is also thankful to Dr. Malavika Dadlani, Dr. T.J. Purakayastha and Dr. S.C. Kaushik IARI, New Delhi for extending their help during the entire course of research. Thanks to the two anonymous reviewers for their critical comments in improving the quality of the manuscript.

\section{References}

Adak, T., Singha, A., Kumar, K., Shukla, S.K., Singh, A., Singh, V.K. 2014. Soil organic carbon, dehydrogenase activity, nutrient availability and leaf nutrient content as affected by organic and 
inorganic source of nutrient in mango orchard soil. J. Soil Sci. Plant Nutri. 14, 394-406.

Asmar, F., Singh, T., Nielsen, G., Nielsen, N.E. 1995. Barley genotypes differ in activity of soluble extracellular phosphatase and depletion of organic phosphorus in the rhizosphere soil. Plant Soil. 172, 117-122.

Barbhuiya, A.R., Arunachalam, A., Pandey, H.N., Arunachalam, K., Khan, M.L., Nath, P.C. 2004. Dynamics of soil microbial biomass $\mathrm{C}, \mathrm{N}$ and $\mathrm{P}$ in disturbed and undisturbed stands of a tropical wetevergreen forest. Europ. J. Soil Biol. 40, 113-121.

Bower, C.A., Wilcox, L.V. 1965. Soluble salts. In: C.A. Black (ed). Methods of soil analysis, ASA Inc., Madison, Wisconsin, USA, pp: 433-451.

Bremner, E., Kesssel, V.C. 1990. Extractability of microbial ${ }^{14} \mathrm{C}$ and $15 \mathrm{~N}$ following addition of variable rates of labeled glucose and ammonium sulphate to soil. Soil Biol. Biochem. 22, 707-713.

Bremner, J.M., Douglas, L.A. 1971. Inhibition of urease activity in soils. Soil Biol. Biochem. 3, 297-307.

Brookes, P.C., Lendham, A., Pruden, G., Jenkinson, D.S. 1985. Chloroform fumigation and the release of soil nitrogen: a rapid direct extraction method to measure microbial biomass nitrogen in soil. Soil Biol. Biochem. 17, 837-842.

Brookes, P.C., Powlson, D.S., Jenkinson, D.S. 1984. Phosphorus in the soil microbial biomass. Soil Biol. Biochem. 16, 169-175.

Brookes, P.C., Powlson, D.S., Jenkinson, D.S. 1982. Measurement of microbial biomass phosphorus in soils. Soil Biol. Biochem. 14, 319-321.

Chhonkar, P.K., Bhadraray, S., Patra, A.K., Purakayastha, T.J. 2007. Experiments in Soil Biology and Biochemistry. Westville Publishing House, New Delhi, India.
Damon, P.M., Bowden, B., Rose, T. and Rengel, Z. 2014. Crop residue contributions to phosphorus pools in agricultural soils: A review. Soil Biol. Biochem. 74, 127-137.

Devi, N.B., Yadava, P.S. 2006. Seasonal dynamics in soil microbial biomass $\mathrm{C}, \mathrm{N}$ and $\mathrm{P}$ in a mixed-oak forest ecosystem of Manipur, North-east India. Ap. Soil Ecol. 31, 220-227.

Dick, W.A., Cheng, L., Wang, P. 2000. Soil acid and alkaline phosphatase activity as $\mathrm{pH}$ adjustment indicators. Soil Biol. Biochem. 32, 1915-1919.

Dinesh, R., Suryanarayana, M.A., Ghosal Chaudhuri, S., Sheeja, T.E., Shiva, K.N. 2006.Long-term effects of leguminous cover crops on biochemical and biological properties in the organic and mineral layers of soils of a coconut plantation. Europ. J. Soil Biol. 42, 147-157.

Feng, W., Zou, X., Schaefer, D. 2009. Above and below ground carbon inputs affect seasonal variations of soil microbial biomass in a subtropical monsoon forest of southwest China. Soil Biol. Biochem. 41, 978-983.

George, T.S., Gregory, P.J., Wood, M., Read, D., Buresh, R.J. 2002. Phosphatase activity and organic acids in the rhizosphere of potential agroforestry species and maize. Soil Biol. Biochem. 34, 1487-1494.

Gomez, K.A., Gomez, A.A. 1984. Statistical Procedure for Agricultural Research. John Wiley and Sons, New York.

Jackson, M.L. 1967. Soil Chemical Analysis. Prentice Hall of India Pvt. Ltd., New Delhi.

Jannoura, R., Bruns, C., Joergensen, R.G. 2013. Organic fertilizer effects on pea yield, nutrient uptake, microbial root colonization and soil microbial biomass indices in organic farming systems. Europ. J. Agron. 49, 32-41. 
Jenkinson, D.S., Ladd, J.N. 1981. Microbial Biomass in Soil: Measurement and Turnover. In: E.A. Paul, J.N. Ladd (ed). Soil Biochemistry, Marcel Dekker, New York, pp: 415-471.

Jenkinson, D.S., Powlson, D.S. 1976. The effects of biocidal treatments on metabolism in soil - I. Fumigation with chloroform. Soil Biol. Biochem. 8, 167-177.

Jia, G.M., Liu, B.R., Wang, G., Zhang, B. 2010. The microbial biomass and activity in soil with shrub (Caragana korshinskii K.) plantation in the semiarid loess plateau in China. Europ. J. Soil Biol. $46,6-10$

Klein, D.A., Loh, T.C., Goulding, R.L. 1971. A rapid procedure to evaluate dehydrogenase activity of soils low in organic matter. Soil Biol. Biochem. 3, 385-387.

Lindsay, W.L., Norvell, W.A. 1978. Development of soil test for zinc, iron, manganese and copper. Soil Sc. Soc. Am. J. 42, 421-428.

Mandal, A., Patra, A.K., Singh, D., Swarup, A., Masto, R.E. 2007. Effect of long-term application of manure and fertilizer on biological and biochemical activities in soil during crop development stages. Biores. Tech. 98, 3585-3592.

Manna, M.C., Swarup, A., Wanjari, R.H., Ravankar, H.N., Mishra, B., Saha, M.N., Singh, Y.V., Sahid, D.K., Sarap, P.A. 2005. Long-term effect of fertilizer and manure application on soil organic carbon storage, soil quality and yield sustainability under sub-humid and semiarid tropical India. Field Crop. Res. 93, 264-280.

Murphy, J., Riley, J.P. 1962. A modified single solution method for the determination of phosphates in natural waters. Anal. Chim. Acta. 27, 31-36.

Nannipieri, P., Giagnoni, L., Renella, G., Puglisi, E., Ceccanti, B., Masciandaro, G., Fornasier, F., Moscatelli, M.C., Marinari, S. 2012. Soil enzymology: classical and molecular approaches. Biol. Fert. Soil. 48, 743-762.
Nguyen, C. 2003. Rhizodeposition of organic $C$ by plants mechanism and controls. Agron. 23, 375-396.

NHB 2012. Indian Horticulture Database-2012. National Horticulture Board, Ministry of Agriculture, Govt. of India, pp: 280.

Olsen, S.R., Cole, C.V., Watanabe, F.S., Dean, L.A. 1954. Estimation of available phosphorus in soils by extraction with sodium bicarbonate. Circular No. 939, USDA, Washington, DC, USA.

Pascual, J.A., Moreno, J.L., Hernández, T., García, C 2002. Persistence of immobilized and total urease and phosphatase activities in a soil amended with organic wastes. Biores. Tech. 82, 73-78.

Patra, A.K., Abbadie, L., Clays-Josserand, A. Degrange, V., Grayston, S.J., Loiseau, P., Louault, F., Mahmood, S., Nazaret, S., Philippot, L., Poly, F., Prosser, J.I., Richaume, A., Le Roux, X. 2005. Effect of grazing on microbial functional groups involved in soil $\mathrm{N}$ dynamics. Ecol. Monog. 75, 65-80.

Peck, G.M., Merwin, I.A., Thies, J.E., Schindelbeck, R.R., Brown, M.G. 2011. Soil properties change during the transition to integrated and organic apple production in a New York orchard. Ap. Soil Ecol. 48, 18-30.

Qian, X., Gu, J., Sun, W., Li, Y.D., Fu, Q.X., Wang, X.J., Gao, H. 2014. Changes in the soil nutrient levels, enzyme activities, microbial community function, and structure during apple orchard maturation. Ap. Soil Ecol. 77, 18-25.

Schollenberger, C.J., Simon, R.H. 1945. Determination of exchange capacity and exchangeable bases in soil - ammonium acetate method. Soil Sc. 59, 13-24.

Shishido, M., Sakamoto, K., Yokoyama, H., Momma, N, Miyashita, S.I. 2008. Changes in microbial communities in an apple orchard and its adjacent bush soil in response to season, land-use, and violet root rot infestation. Soil Biol. Biochem. 40, 1460-1473. 
Snyder, J.D., Trofymow, J.A. 1984. A rapid accurate wet oxidation diffusion procedure for determining organic and inorganic carbon in plant and soil samples. Comm. Soil Sc. Plant Anal. 15, 587-597.

Subbiah, B.V., Asija, G.L. 1956. A rapid test procedure for assessment of available nitrogen in soils. Curr. Sc. 2, 259-260.

Tabatabai, M.A., Bremner, J.M. 1969. Use of $p$-nitrophenol phosphate for assay of soil phosphatase activity. Soil Biol. Biochem. 1, 301307.
Walkley, A., Black, C.A. 1934. An examination of different methods for determining soil organic matter and a proposed modification of the chromic acid titration method. Soil Sc. 37, 29-38.

Wright, A.L., Hons, F.M., Matocha, J.E.Jr. 2005. Tillage impacts on microbial biomass and soil carbon and nitrogen dynamics of corn and cotton rotations. Ap. Soil Ecol. 29, 85-92. 